\title{
PEMETAAN PERAN DAN KONTRIBUSI PEMANGKU KEPENTINGAN DALAM PENGEMBANGAN EKOWISATA DESA BURAI
}

\author{
Debby Fifiyanti ${ }^{1}$, Janianton Damanik ${ }^{1 *}$ \\ ${ }^{1}$ Universitas Gadjah Mada, Indonesia \\ *e-mail: antondmk@ugm.ac.id
}

\begin{abstract}
Abstrak
Kajian tentang desa wisata sudah banyak dilakukan, tetapi persoalan tentang peran pemangku kepentingan belum diungkap secara komprehensif. Penelitian ini bertujuan untuk mengidentifikasi dan mengklasifikasi peran pemangku kepentingan dan pengaruhnya dalam pengembangan ekowisata. Basis metode yang digunakan adalah kualitatif dengan mengandalkan wawancara langsung dan menggunakan platform media online, observasi, dan dokumentasi sebagai cara pengumpulan data. Data diolah untuk mengindentifikasi peran pemangku kepentingan dengan menggunakan NVivo 12 Plus dan dilanjutkan dengan metode analisis melalui pengggunaan matriks kepentingan dan pengaruh para pemangku kepentingan terhadap pengembangan ekowisata. Dari hasil analisis ditemukan sebanyak 13 pemangku kepentingan yang berperan secara berbeda dari lima sektor yaitu pemerintah, swasta, akademisi, lembaga swadaya masyarakat, dan masyarakat. Peran para pemangku kepentingan teridentifikasi dalam tiga kategori, yaitu regulator, fasilitator, dan pengelolah atau pelaksana. Lebih spesifik lagi, berdasarkan pengaruh dan kepetingan terdapat empat pemangku kepentingan berkarakter subjek, empat pemangku kepentingan berperan sebagai pemain kunci, lima pemangku kepentingan berperan sebagai pendukung, dan satu pemangku kepentingan pengikut. Dapat disimpulkan, bahwa peran dan kepentingan mereka bergerak dinamis sesuai dengan komitmen pada prioritas dan target yang ditentukan.
\end{abstract}

Kata Kunci: Peran; Kontribusi; Pemangku Kepentingan; Ekowisata

\section{Abstract}

Many studies on tourism villages have been carried out, but the issue of the role of stakeholders has not been comprehensively resolved. The study aims to identify stakeholders' roles and classify their roles based on their interests and power in the development of ecotourism. The study uses a qualitative approach. Data collection techniques are confirmed by direct interviews and using online media platforms, observation and documentation. The data analysis method to identify the role of stakeholders uses the NVivo 12 Plus, while the analysis method used to classify the roles of stakeholders is carried out using a matrix of stakeholders' interests and power on ecotourism development. This study indicates that 13 stakeholders have different roles in the development of ecotourism from five sectors, namely the government, private sector, academics, non-governmental organizations, and the community. The roles of these stakeholders are divided into three variations of roles, namely regulator, facilitator, and manager or implementer. Then, the results of the classification of the roles of stakeholders based on their interests dan powers show that there are four stakeholders as subjects, four stakeholders as a key player, five stakeholders as context setters, and one stakeholder as a crowd. It could be concluded that their roles and interests move dynamically following the commitment to the determined priorities and targets.

Keywords: Stakeholder; Role; Contribution; Ecotourism

This is an open access article under the CC BY-SA license.

Copyright $\odot 2021$ by Author. Published by Universitas Pendidikan Ganesha.

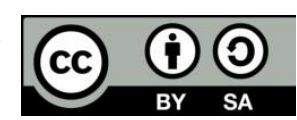

\section{PENDAHULUAN}

Para ahli mengklaim, bahwa ekowisata berpotensi besar untuk berkembang di tengah-tengah terjadinya pergeseran preferensi pasar dan produk yang mengutamakan karakteristik unik, berbasis lokal atau asli (Fennel, 2008; Damanik dan Weber 2006). Berbeda dengan tipe produk pariwisata massal, ekowisata cenderung berdampak lingkungan minimum, mendorong apresiasi maksimal terhadap budaya 
lokal, memberikan manfaat lebih besar kepada masyarakat lokal dan menawarkan kepuasan 'rekreasi' maksimal dan pengalaman bernilai tinggi bagi wisatawan (Kiper, 2013). Lebih dari itu, ekowisata terbukti mampu memajukan konservasi lingkungan dan meningkatkan kesadaran wisatawan dan masyarakat lokal tentang kelestarisan lingkungan maupun budaya setempat (Saidmamatov, et al., 2020).

$$
\text { Kontribusi ekowisata yang }
$$
mendukung pariwisata berkelanjutan (Fennel, 2008; Hill dan Gale, 2009) mendorong pengembangan ekowisata menjadi kajian yang menarik perhatian para ahli yang lain. Chachava dan Khoshtaria (2017) misalnya, menemukan kontribusi signifikan ekowisata pada keberkelanjutan ekologi, ekonomi dan sosial, peningkatan pengetahuan ilmiah tentang sejarah, arkeologi, lingkungan, tata ruang, dan pendidikan bagi penduduk setempat. Selain bagi masyarakat, ekowisata juga berkontribusi bagi peningkatkan otentisitas pengalaman wisatawan yang merupakan salah satu parameter kepuasan berwisata (Wiseza, 2017). Ditunjukkan oleh Saidmamatov dan kawan-kawan (2020), bahwa kesadaran lingkungan dan konservasi yang tinggi pada pemangku kepentingan, khususnya tour operator dan komunitas lokal, akan menjamin keberlanjutan ekowisata di kawasan yang fragil.

Kajian penting namun masih terbatas dilakukan adalah peran kunci pemangku kepentingan dalam pengembangan ekowisata. Tulisan Diamantis (2018) mencoba merangkum analisis para ahli tentang dinamika peran pemangku kepentingan dalam ekowisata tetapi kurang menyoroti secara khusus karakter peran tersebut. Peran yang sering dimainkan setiap pemangku kepentingan condong pada tipe artifisial yang hanya membatasi diri pada apa yang memberikan keuntungan bagi diri atau pihaknya. Hal ini juga ditunjukkan oleh peneliti lain yang menemukan kemitraan yang solid tidak terbentuk dalam pengembangan destinasi ekowisata maritim. Ego- sektoral yang kuat mengakibatkan kemitraan pemangku kepentingan sulit dibangun dalam jangka panjang (Damanik, 2016).

Studi yang bertujuan untuk mengurai klasifikasi peran dan kontribusi peran tersebut terhadap perkembangan ekowisata di tingkat mikro, yakni desa masih terbatas. Padahal kajian sejenis sangat penting setidaknya untuk menjawab pertanyaan, apakah peran yang dijalankan oleh pemangku kepentingan lebih kontributif ekowisata di tingkat mikro dan kontribusi pihak mana yang lebih dominan. Gambaran yang lebih rinci tentang hal itu akan menambah pemahaman kritis tentang bagaimana orkestrasi peran tersebut berkontribusi atau juga menghambat perkembangan ekowisata.

Peran pemangku kepentingan merupakan salah satu kunci sukses dalam pengembangan kegiatan. Peran tersebut memiliki perbedaan sesuai dengan karakteristik organisasi yang diwakilinya. Reed dan kawan-kawan (2009) menyatakan bahwa klasifikasi para pemangku kepentingan dibagi menjadi dua yaitu berdasarkan kepentingan dan pengaruh. Kepentingan mendorong pihak-pihak melakukan interaksi dengan mitranya di dalam melakukan suatu tindakan yang diharapkan memberikan manfaat bagi diri atau organisasinya sambil mengharap mitranya juga melakukan hal yang sama. Pengaruh atau kekuatan merupakan modal di dalam interaksi dengan pihak lain yang diharapkan dapat menggalang kerja sama yang seimbang. Pengaruh dan kepentingan tersebut menentukan posisi aktor-aktor sebagai subjek, pemain kunci, pendukung, atau pengikut.

Pemangku kepentingan ini memiliki peran strategis dalam pengembangan ekowisata. Seperti diketahui, ekowisata merupakan salah satu bentuk kegiatan yang bertujuan untuk melestarikan lingkungan dan budaya serta kesejahteraan masyarakat setempat (Saidmamatov, et al., 2020). Pengembangan ekowista membutuhkan peran aktor secara aktif 
agar sumber daya alam dan budaya yang menjadi basis aktivitas utama dapat terkelola secara tepat. Aktor-aktor yang memiliki kontribusi secara spesifik dapat memudahkan pengelolaan ekowisata untuk mengimplementasikan prinsip pelestarian yang bertanggung jawab (Sheng-Hshiung et al., 2006). Terkait dengan hal itu, keberhasilan ekowisata tidak hanya diukur dari rutinitas kunjungan wisatawan namun juga dari sejauh mana prinsip-prinsip ekowisata diterapkan di dalam matarantai pengelolaannya.

Pengembangan ekowisata memiliki dua tujuan utama yaitu meningkatkan pendapatan masyarakat lokal dan menjaga lingkungan alam. Menurut Choi \& Sirakaya (2006), tidak mudah untuk menggabungkan antara konservasi alam dan peningkatan perekonomian masyarakat, sehingga pengembangan membutuhkan peran dari berbagai pemangku kepentingan yang diharapkan mampu membantu melaksanakan perencanaan pengembangan kegiatan(Walter, 2016).

Pemangku kepentingan dalam pengembangan suatu kawasan ekowisata tentunya memiliki peran dan klasifikasinya masing-masing berdasarkan pengaruh dan kepentingannya yang terdiri dari empat golongan yaitu pemain kunci, subjek, pendukung, dan pengikut (Bryson, 2004).

Mathis (2000) menyatakan bahwa pemangku kepentingan memiliki tiga jenis peran yang dijalankan melalui keterlibatanya dalam pengembangan suatu kawasan wisata, yakni: a) sebagai regulator, yaitu peran yang dilakukan melalui pembuatan peraturan dan kebijakan terkait pegembangan kawasan pariwisata; b) sebagai fasilitator yaitu peran yang dilakukan untuk membantu memenuhi kebutuhan masyarakat guna mencapai tujuan kegiatan pariwisata pada suatu kawasan wisata; dan c) sebagai pengelola dan pelaksana atas suatu kegiatan teknis yang khusus terkait pengembangan suatu kawasan wisata secara mikro.
Peran terakhir ini biasanya dilakukan oleh masyarakat.

Sejauh ini kontribusi peran pemangku kepentingan dalam pengembangan ekowisata, khususnya terkait dengan keterlibatan sektor swasta yang memiliki bisnis inti yang berbeda dengan pariwisata masih sedikit dikaji sehingga informasi ini dibutuhkan untuk melihat peluang pengembangan ekowisata di perdesaan yang selama ini masih banyak bertumpu pada uluran tangan pemerintah dan pada kenyataannya masih sangat terbatas. Oleh karena itu, penelitian ini bertujuan untuk mengidentifikasi dan menganalisis peran pemangku kepentingan serta klasifikasi peran tersebut berdasarkan kepentingan dan pengaruh dalam pengembangan ekowisata berbasis komunitas di sebuah desa di Sumatera Selatan.

\section{METODE}

Penelitian ini dilakukan di Desa Ekowisata Burai, Ogan Ilir, Sumatera Selatan, dengan menggunakan pendekatan kualitatif. Proses penelitian dimulai dari perumusan pertanyaan, prosedur, pengumpulan data spesifik dari partisipan, analisis data, hingga interpretasi data (Creswell, 2013).

Pengumpulan data dilakukan dengan metode wawancara mendalam, baik secara langsung maupun online, observasi, dan dokumentasi. Data yang dikumpulkan terdiri dari data primer dan data sekunder. Data primer didapatkan melalui wawancara dengan informan yang terpilih melalui metode snowball sampling. Cara ini efektif untuk menjaring data yang spesifik dari jumlah informan yang sedikit dan kemudian bertambah dari informan yang lebih banyak (Sugiyono, 2009). Observasi non-partisipan dilakukan untuk melihat perkembangan fisik desa ekowisata beserta aktivitas di dalamnya. Data sekunder terdiri dari dokumen pengurus desa ekowisata, kelompok perajin, Pertamina, pemerintah desa, dan internet yang terkait dengan peran pemangku kepentingan dan klasifikasi 
berdasarkan pengaruh dan kepentingannya.

Tahapan analisis yang dilakukan dalam penelitian ini antara lain sebagai berikut.

1) Identifikasi Peran Pemangku Kepentingan

Identifikasi peran para pemangku kepentingan dilakukan dengan tiga tahapan yaitu reduksi data, penyajian data, dan penarikan kesimpulan. Data yang diperoleh mengenai peran pemangku kepentingan dirangkum kemudian dipilih data yang dianggap penting sesuai dengan kebutuhan penelitian guna memperoleh data dan informasi yang lebih tajam.

Data yang telah dipilih melalui proses seleksi dibuat menjadi sebuah ringkasan singkat dan dikelompokkan agar membentuk suatu pola yang lebih mengerucut. Dalam hal ini, pengelompokan berdasarkan peran pemangku kepentingan yaitu peran regulator, fasilitator, dan pelaksana. Selanjutnya, data tersebut diuraikan agar informasi mengenai identifikasi peran pemangku kepentingan dapat terlihat secara jelas dan menyeluruh sehingga dapat dilakukan penarikan kesimpulan secara tepat. Alat bantu yang digunakan dalam menganalisis data ini menggunakan Nvivo lus 12 dengan cara menentukan code dan note, melakukan proses pengkodean, dan pendeskripsian hasil.

2) Klasifikasi Pemangku Kepentingan Berdasarkan Kepentingan dan Pengaruh

Metode analisis dalam mengklasifikasi pemangku kepentingan berdasarkan tingkat kepentingan dan pengaruhnya menggunakan sebuah matriks. Berdasarkan pengaruh dan kepentingannya pemangku kepentingan terdiri dari empat golongan yaitu: subjek, pemain kunci, pendukung, dan pengikut (Reed et al., 2009). Klasifikasi tersebut nampak pada Gambar 1.

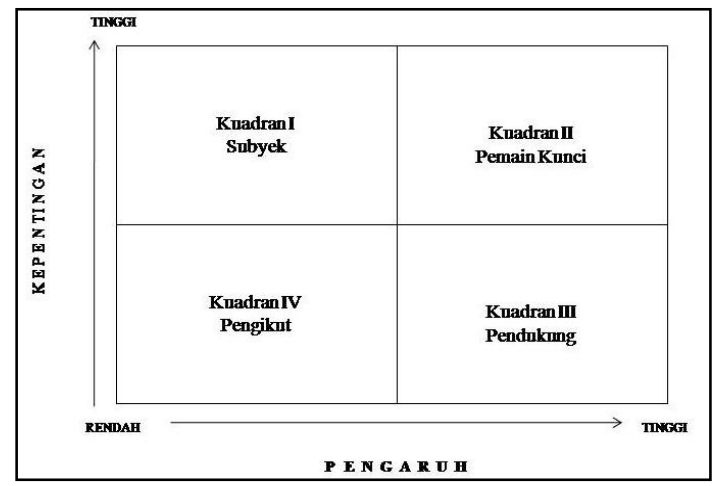

Gambar 1. Matriks klasifikasi pemangku kepentingan

\section{HASIL DAN PEMBAHASAN}

Desa Ekowisata Burai merupakan desa terpencil yang terletak paling ujung dari kecamatan sehingga akses sulit dan mutu jalan buruk. Mayoritas penduduknya miskin dan bekerja sebagai petani, nelayan,serta pengrajin songket.

Berdasarkan kondisi tersebut, perlahan pemerintah desa dan masyarakat mulai berinisiasi untuk mengembangkan sektor pariwisata sebagai salah satu strategi pembangunan desa. Hal ini dikarenakan kawasan tersebut memiliki potensi alam dan kebudayaan yang dapat dikembangkan untuk dijadikan suatu destinasi pariwisata.

Aktor utama yang menjadi inisiator dalam pengembangan pariwisata ialah Bapak Willy Sandi yang merupakan masyarakat lokal dan tenaga honorer di salah satu instansi. Ide dan gagasan beliau dalam mengembangkan desa untuk menjadi desa wisata didukung oleh kepala desa. Pada tahun 2017, pegembangan pariwisata di Desa Burai mengusung konsep kampung warnawarni yaitu rumah penduduk yang dicat dengan berbagai macam warna untuk dijadikan spot foto bagi wisatawan. Namun, tokoh masyarakat ini merasa kegiatan pariwisata desa ini harus lebih dikembangkan lagi dalam segi konsep, pengadaan sarana prasarana, produk wisata yang lebih menarik dan berkelanjutan. 
Melalui bantuan pemerintah
daerah, pengembangan pariwisata di
desa tersebut akhirnya dibantu oleh PT
Pertamina Asset II Prabumulih yang
kebetulan sedang melakukan kegiatan
pengembangan desa di wilayah
operasional perusahaan melalui
program CSR guna memenuhi kebutuhan pemerintah dan masyarakat. Pada tahun 2018, perusahaan ini resmi menjadi pemangku kepentingan yang berkontribusi dalam pengembangan pariwisata di Desa Burai.

Kelembagaan desa yang mendukung perencanaan yang bersifat sinergis antar pemangku kepentingan menjadi salah satu cikal bakal terlaksananya pengembangan ekowisata. Kekuatan kelembagaan dan komitmen masyarakat untuk berkontribusi dan bertanggug jawab menjadi salah satu kunci dalam pengembangan pariwisata sehingga terjalin kerjasama antar pemangku kepentingan dan masuknya pihak swasta untuk memberikan bantuan anggaran dana melalui program CSR.

\section{Identifikasi Peran Pemangku Kepentingan}

Berdasarkan hasil wawancara dan observasi, terindikasi berbagai macam pemangku kepentingan yang berperan dalam pengembangan ekowisata di Desa Ekowisata Burai. Para pemangku kepentingan yang terlibat dalam pengembangan dan pengelolahan ekowisata memiliki tugas pokok dan fungsi masing-masing.

Berdasarkan hasil group query analysis pada gambar tersebut menunjukkan terdapat tiga belas (13) pemangku kepentingan yang berperan dalam pengembangan ekowisata seperti terlihat pada Gambar 2. Jenis peran para pemangku kepentingan dalam pengembangan ekowisata tersebut dibagi menjadi tiga yaitu regulator, fasilitator, dan pelaksana (Sekhri, 2009)

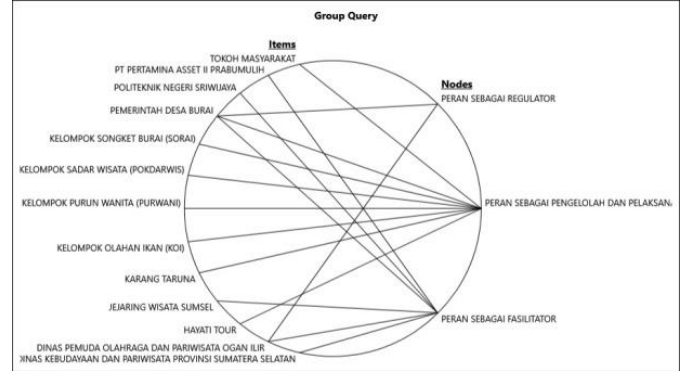

Gambar 2. Hasil analisis identifikasi peran pemangku kepentingan

\section{Peran sebagai Regulator \\ Peran sebagai regulator} merupakan peran yang paling identik dengan sektor pemerintah dan tidak dapat digantikan oleh pemangku kepentingan yang lain karena pemerintah memiliki peran membuat kebijakan dan peraturan guna mengatur mekanisme pembangunan dan pengembangan (Prastika, 2017).

Dalam pengembangan ekowisata di desa tersebut, terdapat tiga pemangku kepentingan yang berasal dari sektor pemerintah yaitu Dinas Kebudayaan dan Pariwisata Provinsi Sumatera Selatan, Dinas Pemuda, Olahraga, dan Pariwisata Ogan Ilir, serta Pemerintah Desa Burai.

Berdasarkan hasil wawancara, terdapat dua pemangku kepentingan dari sektor pemerintah yang berperan sebagai regulator yaitu Pemerintah Desa Burai dan Dinas Pemuda, Olahraga, dan Pariwisata Ogan Ilir.

$\mathrm{Hal}$ ini terlihat dari berbagai kebijakan dan peraturan yang dibuat dalam pengembangan ekowisata antara lain pemerintah desa, pemangku kepentingan yang memiliki kewenangan untuk memberikan izin kepada para aktor yang turut berperan dalam pengembangan dan pemberian izin penggunaan lahan desa. Peran pemerintah desa sebagai regulator dianggap wajar karena pejabat yang bersangkutan merupakan aktor yang memiliki kendali penuh dalam menentukan regulasi di kawasan desa tersebut. 
Pemangku kepentingan lain yang memiliki peran sebagai regulator adalah Dinas Pemuda, Olahraga, dan Pariwisata Ogan Ilir. Meskipun memiliki peran sebagai regulator, instansi ini tidak memiliki peran secara komprehensif seperti pemerintah desa. Berdasarkan hasil wawancara, peran regulator yang dimiliki oleh pejabat tersebut hanya sebatas memberikan izin pembentukan Kelompok Sadar Wisata (Pokdarwis) melalui penerbitan Surat Keputusan (SK).

\section{Peran sebagai Fasilitator}

Peran sebagai fasilitator ialah peran yang dimiliki oleh para pemangku kepentingan yang memberikan kontribusi untuk membantu memenuhi kebutuhan masyarakat dalam pengembangan perencanaan pariwisata guna mencapai tujuan yang direncanakan.

Bentuk kontribusi bantuan yang dilakukan oleh pemangku kepentingan yang berperan sebagai fasilitator tidak hanya pengadaan fasilitas fisik seperti pembangunan sarana dan prasarana, namun juga dapat dalam pengadaan fasilitas nonfisik seperti pelatihan dan pendampingan kepada masyarakat. Para pemangku kepentingan yang berperan sebagai fasilitator memiliki pengaruh yang cukup besar dalam pengembangan suatu perencanaan (Zubayr et al., 2014)

Berdasarkan hasil croosstab query analysis menggunakan alat uji software NVivo 12 Plus, pada Gambar 3 berikut merupakan data pemangku kepentingan yang berperan sebagai fasilitator dengan kontribusinya masing-masing.

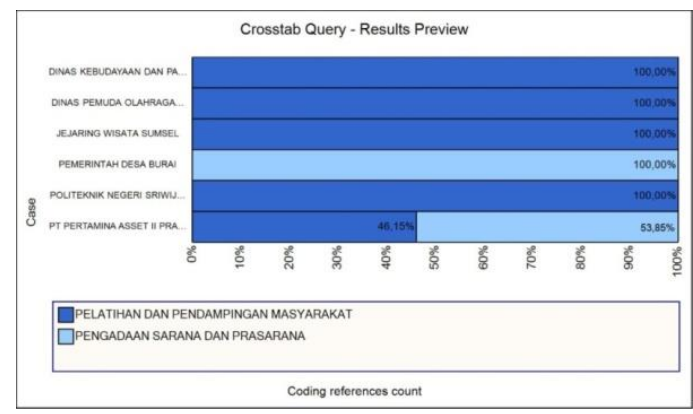

Gambar 3. Peran pemangku kepentingan sebagai fasilitator
Hasil tersebut menunjukkan pemangku kepentingan sebagai faslitator dapat melalui pemberian pelatihan, peningkatan keterampilan kepada masyarakat, dan pembangunan sarana prasarana.

Terdapat lima pemangku kepentingan yang berkontribusi dalam memberikan pelatihan dan pendampingan kepada masyarakat dan dua pemangku kepentingan yang membantu pengadaan sarana dan prasarana.

Adapun pemangku kepentingan yang berkontribusi dalam membantu pengadaan sarana dan prasarana yaitu Pemerintah Desa Burai dan PT Pertamina. Pemerintah Desa Burai memiliki persentasi keterlibatan 100\% dalam pengadaan sarana prasarana, sedangkan PT Pertamina memiliki dua keterlibatan yaitu dalam pengadaan sarana prasarana dengan persentasi keterlibatan sebesar $53,85 \%$ dan pengadaan pelatihan dan pendampingan masyarakat sebesar $46,15 \%$. Hal ini sesuai juga dengan pernyataan dari Kepala Desa Burai yang menyatakan :

"....pegembangan ekowisata di desa dibantu oleh banyak PT Pertamina dalam bentuk bantuan dana, pendampingan, dan pelatihan kepada masyarakat lokal. Sedangkan Pemerintah Desa berkontribusi dalam pembangunan fasilitas pariwisata"

Berdasarkan hasil wawancara, fasilitas sarana dan prasarana yang dibangun oleh pemerintah desa dengan menyisihkan $70 \%$ dari anggaran dana desa. Adapun fasilitas yang dibangun yaitu dermaga dan pengadaan perahu besar untuk kegiatan wisata susur sungai. Selain itu, pemangku kepentingan yang terlibat adalah PT Pertamina Asset II Prabumulih. Adapun pengadaan sarana prasarana yang diberikan antara lain perbaikan infrastruktur jalan, post icon foto pada gapura desa, gazebo, rumah gallery, toilet dan ruang ganti, serta pengadaan pelampung dan ban untuk kelengkapan fasilitas susur sungai. 
Selain dukungan pembangunan sarana prasarana, terdapat pemangku kepentingan lainnya yang berperan sebagai fasilitator yang berkonribusi dalam bentuk pemberdayaan kepada masyarakat lokal. Proses pemberdayaan masyarakat perlu ada kolaborasi dan koordinasi dari masingmasing pemangku kepentingan yaitu pemerintah, swasta, dan masyarakat (Sulistyani, 2004).

Terdapat lima pemangku kepentingan yang terlibat dalam pemberdayaan masyarakat yaitu PT Pertamina Asset II Prabumulih, Dinas Kebudayaan dan Pariwisata Provinsi Sumatera Selatan, Dinas Pemuda, Olahraga, dan Pariwisata Ogan Ilir, Jejaring Wisata Sumsel, dan Politeknik Negeri Sriwijaya. Upaya pemberdayaan masyarakat dilakukan secara simultan oleh para pemangku kepentingan yaitu pada tahun 2018 hingga 2019. Disebutkan oleh Sunaryo (2013), bahwa upaya pemberdayaan masyarakat melalui kepariwisataan pada hakikatnya harus bertujuan untuk meningkatkan kapasitas dan peran masyarakat dalam pembangunan kepariwisataan, memberikan manfaat positif bagi kesejahteraan ekonomi masyarakat, serta membentuk pengelolaan atau pelaku pariwisata di suatu destinasi untuk bertanggung jawab terhadap operasional destinasi, dan menunjang keberlangsungan dari destinasi tersebut.

$$
\text { PT Pertamina merupakan }
$$

pemangku kepentingan yang menyadari bahwa desa ini memiliki potensi yang dapat digali untuk mengembangkan kegiatan ekowisata sehingga perusahaan melakukan pemetaan potensi wisata yang akan dikembangkan dan dapat dijadikan produk wisata.

Berdasarkan hasil pemetaan ditemukan bahwa potensi produk ekowisata antara lain wisata alam berupa susur sungai, kebudayaan menenun songket, kebudayaan menganyam purun, dan kuliner olahan ikan. Setelah mengetahui potensi wisata yang dapat dikembangkan menjadi produk wisata, para aktor dari pihak PT Pertamina mencoba untuk memberdayakan masyarakat dengan membentuk beberapa kelompok masyarakat seperti Kelompok SORAI (Songket Burai), Kelompok KOI (Kelompok Olahan Ikan), dan Kelompok PURWANI (Purun Wanita).

Untuk mengembangakan potensi menganyam purun dan olahan makanan berbahan dasar ikan agar dapat dijadikan produk wisata, perusahaan menggandeng pihak ketiga untuk memberikan pelatihan kepada masyarakat. Seharusnya materi pelatihan harus relevan dengan kebutuhan calon peserta agar ia dapat digunakan dalam praktik efektif (Anwar, 2007). Namun demikian, dalam kenyatan hal itu sulit terealisasi. Misalnya, materi pelatihan pengolahan bahan dasar ikan menjadi kemplang, pempek, dan pindang condong secara umum atau kurang praktis untuk mendorong munculnya diversifikasi produk. Akibatnya, kegiatan pelatihan dianggap kurang efektif. Hal ini selaras dengan hasil wawancara kepada salah satu tokoh masyarakat yang mengatakan :

".... selain membantu dalam pembangunan sarana dan prasarana, PT Pertamina juga membentuk beberapa kelompok masyarakat yang kemudian diberikan pelatihan untuk membuat produk ekowisata. Pertamina menggandeng pihak ketiga untuk memberikan materi pelatihan anyaman purun dan kuliner olahan ikan"

Pemangku kepentingan lainnya yang juga berperan sebagai fasilitator dalam pengembangan ekowisata adalah Dinas Pemuda, Olahraga, dan Pariwisata Ogan Ilir, Dinas Kebudayaan dan Pariwisata Provinsi Sumatera Selatan, Jejaring Wisata Sumsel, dan Politeknik Negeri Sriwijaya. Keempat pemangku kepentingan tersebut melakukan kolaborasi guna memberikan kontribusinya dalam pengembangan ekowisata berupa pengadaan pelatihan kepada masyarakat dalam kurun waktu satu tahun sebanyak lima kali.

Periode pelatihan pertama diberikan oleh Jejaring Wisata Sumsel. Keterlibatan lembaga ini dalam 
pengembangan ekowisata sejak tahun 2018 merupakan bagian dari upaya untuk menjalankan visi dan misi lembaga dalam mengembangkan objek wisata di Sumatera Selatan.

Saat lembaga ini mulai terlibat, belum terbentuk Kelompok Sadar Wisata (Pokdarwis) di Desa Ekowisata Burai sehingga destinasi wisata tersebut masih dikelolah oleh Bapak Willy dan beberapa masyarakat lainnya. Adanya Pokdarwis diharapkan dapat menjadi motivator dan penggerak dalam upaya meningkatkan kesiapan dan kepedulian masyarakat di sekitar destinasi pariwisata sebagai tuan rumah yang baik.

Berdasarkan latar belakang kondisi tersebut, Jejaring Wisata Sumsel berinisiasi mengusung tema pelatihan pemberdayaan masyarakat melalui Kelompok Sadar Wisata serta memberikan edukasi tentang membangun organisasi yang ideal kepada para pengelola sehingga setiap anggota yang terlibat dapat bertanggung jawab atas tugas dan wewenang masing-masing. Hal ini merujuk pada pernyataan ketua Jejaring Wisata Sumsel yang menyatakan :

"... salah satu bentuk pendampingan masyarakat yang kami lakukan ialah membantu masyarakt untuk membangun organisasi yang ideal dan membantu mendirikan Pokdarwis"

Pemangku kepentingan lainnya yang berperan sebagai fasilitator dalam pengembangan ekowisata adalah Dinas Kebudayaan dan Pariwisata Provinsi Sumatera Selatan. Keterlibatan instansi ini berawal pada tahun 2018 setelah mendapatkan laporan dari Dinas Pemuda, Olahraga, dan Pariwisata Kabupaten Ogan Ilir yang menyatakan bahwa terdapat salah satu desa di Ogan llir yang memiliki potensi pariwisata yang sedang dikembangkan oleh masyarakat dan pemerintah setempat.

Bentuk pendampingan yang diberikan oleh instansi tersebut kepada masyarakat antara lain dengan mengadakan pelatihan sebanyak dua kali mengenai tata kelola pariwisata dan manajemen homestay.

Narasumber untuk pelatihan dengan topik tata kelola pariwisata adalah Kepala Seksi Daya Tarik Wisata. Narasumber untuk pelatihan dengan topik manajemen homestay adalah Kepala Bidang Promosi dan Pemasaran.

Salah satu syarat menjadi narasumber yaitu memahami materi serta memiliki wawasan yang luas terhadap topik yang disampaikan, dengan kata lain memiliki kompetensi terhadap topik yang disampaikan. Namun, pada beberapa program pelatihan yang diadakan oleh pemangku kepentingan sering kali ditemukan narasumber yang memberikan pelatihan tidak sesuai dengan latar belakang pendidikan atau pekerjaan yang tekuni sehingga pelatihan yang diberikan terkesan hanya untuk simbolis agar program tersebut terlaksana.

Jika merujuk pada pelatihan yang diselenggarakan dengan topik pelatihan manajemen homestay, narasumber yang memberikan pelatihan tidak memiliki latar belakang bidang pekerjaan yang sesuai dengan tema yang disampaikan. Bidang pekerjaan narasumber adalah promosi dan pemasaran, tetapi tema pelatihan yang disampaikan adalah manajemen homestay sehingga tidak ada relevansi antara bidang pekerjaan yang ditekuni dan topik yang diberikan.

Hal tersebut juga serupa dengan pelatihan yang diberikan oleh Dinas Pemuda, Olahraga, dan Pariwisata Ogan llir yang memberikan pelatihan mengenai pemandu wisata. Narasumber yang memberikan pelatihan adalah staff instansi yang pada hakikatnya dirasa tidak memenuhi kompetensi sebagai narasumber dalam pelatihan dengan materi tersebut.

Pemangku kepentingan selanjutnya yang berperan sebagai fasilitator lainnya yaitu Politeknik Negeri Sriwijaya Palembang. Pada tahun 2018, kampus ini juga ikut terlibat dalam pengembangan ekowisata Ketertarikan untuk turut berperan dikarenakan desa 
ini memiliki banyak potensi alam dan kebudayaan yang dapat dikembangkan serta lokasinya yang strategis tidak jauh dari pusat kota Palembang. Selain itu, untuk mengimplementasikan ilmu pariwisata yang dimiliki oleh sektor akademisi serta sebagai wujud penerapan salah satu pilar Tri Dharma Perguruan Tinggi yaitu pengabdian kepada masyarakat.

Narasumber pada penelitian tersebut ialah salah satu dosen yang memiliki kompetensi dalam ilmu kepariwisataan. Adapun materi pendampingan yang diberikan mengenai hospitality. Pemilihan topik penelitian bertujuan untuk memberian edukasi kepada masyarakat tentang penerapan hospitality dalam melayani wisatawan yang datang ke desa serta penerapan sapta pesona. Sapta pesona merupakan salah satu unsur penting yang harus diwujudkan dalam suatu destinasi pariwisata agar terwujudnya lingkungan yang kondusif dan ideal serta untuk mendorong tumbuhnya minat wisatawan melakukan kunjungan.

Dalam pelatihan, ada beberapa hal yang dapat menjadi perhatian para pemangku kepentingan untuk ditinjau kembali guna memberikan hasil yang efektif kepada masyarakat. Werther,Jr (1996) menyatakan bahwa dalam memberikan suatu pelatihan agar mendapatkan hasil yang efektif untuk para peserta, hendaknya materi yang disampaikan memiliki relevensi dengan kebutuhan peserta.

Pada kenyataannya dari berbagai pelatihan tersebut, topik mengenai manajemen homestay dirasa tidak memiliki keterkaitan dengan kebutuhan masyarakat Desa Burai. Hal ini karena dikawasan ekowisata tersebut tidak terdapat homestay yang dibangun atau difasilitasi oleh masyarakat sehingga topik yang diberikan dirasa tidak memiliki relevansi. Berdasarkan hasil wawancara dan observasi, pelatihan tersebut juga tidak memiliki output dalam pengembangan ekowisata karena tidak terlihat adanya fasilitas homestay yang dibangun di desa tersebut setelah pelatihan dilaksanakan.
Rohaniyah (2005) menyatakan bahwa terdapat tiga faktor yang dapat menghambat suatu pemberdayaan yaitu tidak adanya narasumber yang berkompeten pada suatu instansi, pelatihan dan pendampingan kepada masyarakat yang tidak berkelanjutan secara kontinu, dan sikap atau mental masyarakat yang tidak mau belajar dan hanya menginginkan hasil yang cepat. Jika merujuk pada ketiga faktor tersebut, terdapat beberapa komponen yang menjadi perhatian dalam pelatihan ini. Selain topik yang memiliki relevansi dengan kebutuhan masyarakat dan kondisi destinasi, pemilihan narasumber yang berkompeten ternyata menjadi faktor yang juga memengaruhi pelaksanaan suatu pelatihan untuk mendapatkan hasil yang efektif.

Pemberdayaan masyarakat tidak bersifat selamanya, melainkan sampai target masyarakat mampu untuk mandiri, tetapi para pendamping tetap harus memonitoring dan memberikan evaluasi kepada masyarakat (Gunawan, 2009). Oleh karena itu, untuk menjaga kualitas hasil dari suatu pemberdayaan dan pelatihan, pemangku kepentingan sebaiknya menetapkan pola monitoring dan evaluasi yang jelas serta berkelanjutan. Program-program pemberdayaan masyarakat baik dalam bentuk pendampingan maupun pelatihan yang sudah dilakukan kepada masyarakat hendaknya dapat dipelihara, dimonitor, dan dievaluasi kembali.

Pada kenyataannya, seringkali ditemukan program pelatihan yang hanya berumur pendek sesuai dengan umur proyek. Apabila proyek selesai, maka tidak ada lagi pantauan untuk program tersebut. Hal ini juga terlihat dalam pengembangan ekowisata di Desa Burai, selepas dari satu tahun masa pendampingan dan pelatihan kepada masyarakat, saat ini masyarakat telah dituntut untuk mandiri tanpa adanya monitoring serta evaluasi oleh beberapa pemangku kepentingan.

\section{Peran sebagai Pelaksana \\ Peran sebagai pelaksana \\ pengembangan suatu kawasan wisata}


identik dengan peran yang melibatkan masyarakat. Keterlibatan pemangku kepentingan yang berperan sebagai pengelola biasanya dimulai dari tahap perencanaan, proses, pelaksanaan, pengawasan, hingga evaluasi.

Berdasarkan hasil wawancara yang kemudian dianalisis menggunakan group query analysis terdapat delapan pemangku kepentingan yang memiliki peran sebagai pengelola dan pelaksana di Desa Ekowisata Burai. Kelompok masyarakat menjadi aktor paling dominan dalam pengelolahan. Pemerintah desa, karang taruna, Hayati Tour, dan tokoh masyarakat memiliki kontribusi peran yang lebih sedikit sebagai fasilitator untuk menjamin ruang gerak kemandirian masyarakat serta agar proporsi paling besar atas kebermanfaatan pengembangan ekowisata tersebut dapat dirasakan oleh masyarakat.

Pokdarwis merupakan salah satu pemangku kepentingan yang memiliki keterkaitan peran penting dalam pengembangan ekowisata. Salah satu tugasnya adalah menjadi motor penggerak untuk mengajak masyarakat agar terlibat menjadi pelaku pariwisata. Masyarakat yang tergabung dalam Pokdarwis juga bertugas untuk membawa tamu yang berwisata dan mengkoordinatori berbagai aktivitas wisata yang melibatkan kelompok masyarakat lainnya seperti Kelompok SORAI, PURWANI dan KOI. Selain itu, Pokdarwis memiliki peran untuk membuat paket wisata serta mengawasi kinerja setiap aktor lainnya yang berperan sebagai pengelola dan pelaksana.

Peran lainnya yang dilakukan oleh kelompok ini adalah melakukan promosi ekowisata baik melalui media sosial kemudian juga melakukan kerjasama dengan para perusahaan tour and travel. Salah satu perusahaan tour and travel yang bekerjasama dengan Pokdarwis adalah Hayati Tour. Pemangku kepentingan ini juga berperan sebagai pelaksana karena memiliki kontribusi dalam mendatangkan wisatawan ke Desa Ekowisata Burai.

Kerjasama Pokdarwis dengan Hayati Tour merupakan suatu kegiatan simbiosis mutulasime. Perusahaan akan mendapatkan keuntungan finansial dengan mendatangkan wisatawan sedangkan keuntungan bagi pengelola yaitu dapat memangkas anggaran serta tidak perlu melakukan promosi secara masif karena sudah dibantu oleh pihak travel.

Pemangku kepentingan lainnya yang berperan sebagai pengelola dan pelaksana adalah para kelompok masyarakat yang tediri dari Kelompok Songket Burai (SORAI), Kelompok Olahan Ikan (KOI), dan Kelompok Purun Wanita (PURWANI). Kelompok masyarakat berperan untuk memberikan edukasi kepada wisatawan yang berminat untuk belajar menenun songket, menganyam purun, atau memanggang kemplang. Kegiatan yang dilakukan oleh para pengelola dan dapat menjadi pekerjaan insidental masyarakat. Manfaat lain yang didapat yaitu produk yang awalnya merupakan hasil kerajinan tangan yang digunakan secara pribadi atau didistribusikan ke pasar dan toko suvenir, sekarang dapat dijual langsung kepada wisatawan sehingga produsen lebih mudah dalam melakukan proses jual beli.

Pemerintah desa, karang taruna, dan tokoh masyarakat juga memiliki peran sebagai pengelolah. Namun, pemangku kepentingan ini tidak terlibat langsung dalam manajemen pengembangan ekowisata. Ketiganya memiliki tugas dan tanggung jawab untuk mengawasi kinerja pengelola dan perkembangan kegiatan ekowisata serta memastikan segala aktivitas ekowisata berjalan dengan kondusif. Selain itu, per tiga bulan sekali ketiga pemangku kepetingan tersebut akan melakukan evaluasi segala kegiatan-kegiatan ekowisata yang telah dilakukan di Desa Ekowisata Burai.

Pada awal perkembangannya, Desa Burai hanya diinisiasi oleh satu orang warga masyarakat yaitu Bapak Willy Sandi, kemudian mendapat 
dukungan pemerintah desa berkat komitmen warga tersebut merintis kegiatan ekowisata. Inisiasi itu semakin mendapat perhatian banyak pihak dan sekarang telah berubah menjadi destinasi wisata yang didukung oleh banyak pemangku kepentingan yang memiliki tujuan yang sama serta memiliki target pembangunan yang luar biasa bagi desa dan masyarakat sekitar.

Kerjasama dan kolaborasi antar pemangku kepentingan terjalin sangat erat sehingga dapat mengembangkan desa tersebut hingga kondisi saat ini. Meskipun terdapat beberapa pemangku kepentingan sudah menyelesaikan pendampingan sehingga tidak adanya monitoring lebih lanjut, namun pihak pengelola tetap terus mencoba untuk melakukan pengembangan desa agar menjadi desa yang lebih mandiri.

\section{Klafisikasi Peran Pemangku Kepentingan Berdasarkan Kepentingan dan Pengaruh}

Reed et al., (2009) menyatakan bahwa klasifikasi pemangku kepentingan berdasarkan pengaruh dan kepentingannya terbagi ke dalam empat golongan yaitu subjek, pemain kunci, pendukung, dan pengikut. Peran pemangku kepentingan memiliki pengaruh yang penting dalam pengembangan ekowisata. Selain itu, hubungan antar lembaga dalam berkolaborasi juga merupakan pemicu pengembangan suatu destinasi. Gambar 4 berikut merupakan matriks analisis peran para pemangku kepentingan berdasarkan aspek kepentingan dan aspek pengaruh.

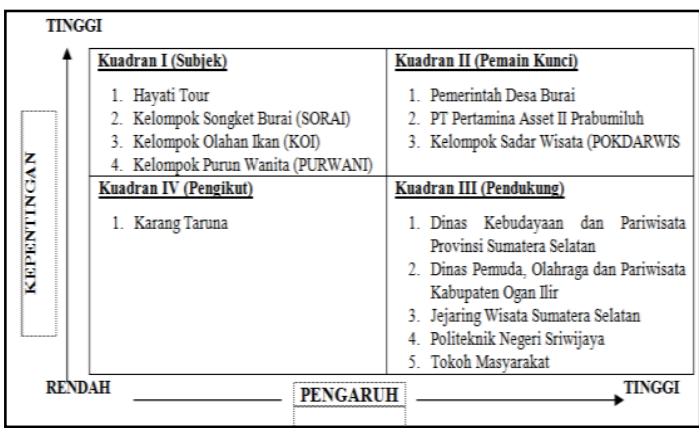

Gambar 4. Matriks hasil olah data analisis peran pemangku kepentingan
Berikut merupakan interpretasi dari klasifiksi peran para pemangku kepentingan berdasarkan aspek kepentingan dan aspek pengaruh yang telah dikategorikan dalam matriks tersebut antara lain sebagai berikut.

\section{Kuadran I (Subjek) \\ Pada posisi kuadran I terdapat} empat pemangku kepentingan yang terdiri dari satu sektor swasta dan tiga sektor masyarakat.Terkait dengan hal ini, pandangan Reed et al., (2009) yang menyatakan, bahwa subjek merupakan pemangku kepentingan yang memiliki kepentingan yang tinggi tetapi pengaruhnya rendah, menjadi signifikan. Oleh karena itu, pemangku kepentingan yang masuk dalam kuadran I merupakan pemangku kepentingan yang perlu diberdayakan, dilibatkan, dan didampingi lebih jauh dalam pengelolaan ekowisata.

Pemangku kepentingan sektor swasta yaitu Hayati Tour tentunya memiliki kepentingan yang tinggi dalam pengembangan ekowisata. Hal ini karena Hayati Tour merupakan perusahaan bisnis yang mengincar keuntungan finansial pada setiap kegiatan perjalanan wisata. Adapun manfaat yang diperoleh perusahaan ini terhadap kegiatan ekowisata antara lain sebagai mata pencaharian serta dapat menjalin interaksi dan komunikasi kepada masyarakat dan wisatawan.

Pemangku kepentingan lainnya yang juga memiliki kepentingan yang tinggi dalam pengembangan ekowisata adalah dari sektor masyarakat yang terdiri dari SORAI, KOI, dan Purwani. Hal ini dikarenakan ketiga kelompok masyarakat tersebut mendapatkan manfaat seperti sumber pendapatan, menambah skill dan wawasan, serta sebagai media untuk berinteraksi dengan wisatawan atau masyarakat luar.

Kegiatan pariwisata dapat membantu masyarakat untuk mendapatkan pekerjaan insidental guna menambah pendapatan. Manfaat lain yang didapat karena adanya akivitas ekowisata di desa ini yaitu dapat 
mendatangkan banyak wisatawan sehingga membuka akses keramaian serta dapat menjalin interaksi dengan masyarakat luar. Hal ini merujuk pada informasi yang diberikan oleh ketua kelompok masyarakat:

"....adanya kegiatan pariwisata di Desa Burai memberikan dampak positif bagi masyarakat yang tergabung dalam kelompok masyarakat"

\section{Kuadran II (Pemain Kunci)}

Pemangku kepentingan yang berada pada kuadran II disebut sebagai pemangku kepentingan pemain kunci yang memiliki aspek kepentingan dan aspek pengaruh yang tinggi dalam pengembangan ekowisata. Pada posisi kuadran ini terdapat tiga pemangku kepentingan yang terlibat.

Seperti yang disampaikan oleh Sembiring \& Basuni (2010), pemangku kepentingan sebagai pemain kunci mempunyai kekuasaan secara legal dalam pegelolahan kawasan. Pemerintah desa dan Pokdarwis memiliki kepentingan yang tinggi dalam aspek manajemen pengelolaan ekowisata seperti perencanaan, pelaksanaan, pengawasan, dan evaluasi. Selain itu, manfaat yang didapatkan antara lain dapat menjadi sumber pemasukan kas desa dan sebagai media promosi daerah, sedangkan manfaat bagi Pokdarwis ialah dapat menambah wawasan dan kemampuan dalam kegiatan pariwisata sehingga mampu menjadi sumber mata pencaharian. Kedatangan wisatawan membuat desa ini menjadi ramai sehingga terjadinya interaksi sosial antara masyarakat dan wisatawan.

Pemangku kepentingan lainnya yang memiliki kepentingan cukup tinggi dalam pengembangan ekowisata adalah PT Pertamina. Hal ini dikarenakan perusahaan tersebut beroperasional di kawasan Kabupaten Ogan Ilir, Prabumulih. Sehingga, guna menjamin kegiatan operasional perusahaan tetap berjalan lancar di daerah tersebut, PT Pertamina mengambil peran dalam pengembangan ekowisata sesuai dengan rekomendasi pemerintah setempat terhadap pemilihan destinasi wisata. Hal ini dilakukan sebagai bentuk tanggungjaawab sosial dan lingkungan perusahaan kepada masyarakat disekitar kawasan operasional.

\section{Kuadran III (Pendukung) \\ Pemangku \\ kepentingan \\ pendukung merupakan pemangku} kepentingan yang memiliki kepentingan yang rendah namun pengaruhnya terhadap pengembangan ekowisata tinggi. Pada posisi kuadran III ini terdapat lima pemangku kepentingan yang terlibat.

Pemangku kepentingan pendukung akan melakukan upaya yang maksimal guna tercapainya suatu rencana kegiatan (Maryono et al., 2005). Para aktor tidak memiliki kepentingan yang signifikan bagi instansi dan lembaganya karena semua manfaat diperuntukkan untuk masyarakat. Namun demikian, para pemangku kepentingan tersebut tetap melakukan perannya secara maksimal.

Dinas Kebudayaan dan Pariwisata Sumatera Selatan bersama Dinas Pemuda, Olahraga, dan Pariwisata Ogan llir mendukung penuh segala upaya kegiatan dan program yang dilakukan guna untuk pengembangan ekowisata. Hal ini terlihat dari kapasitas sumber daya manusia atau aktor dari kedua instansi yang terlibat yakni Kepala Seksi Pengembangan Destinasi Pariwisata dari masing-masing instansi.

Pemangku kepentingan tersebut juga berkolaborasi dalam memberikan pelatihan dan pendampingan bagi masyarakat guna membentuk masyarakat yang sadar wisata serta membantu mengembangkan kegiatan kepariwisataan. Kedua instansi tersebut juga turut membantu melakukan promosi, baik melalui media sosial maupun secara langsung di setiap kegiatan pariwisata daerah maupun provinsi. Hal ini diharapkan dapat menjadi salah satu cara agar destinasi ini dapat dikenal oleh masyarakat luas dan menarik wisatawan untuk berkunjung. 
Pemangku kepentingan pendukung lainnya adalah Jejaring Wisata Sumsel yang melakukan kontribusi peran antara lain memberikan edukasi tentang pengelolahan kegiatan wisata dan pengadaan Pokdarwis pada suatu kawasaan destinasi, membangun organisasi wisata yang ideal, serta menjadi penghubung antara pihak pengelolah dan pemangku kepentingan yang lain. Lembaga ini juga membantu dalam pendirian Pokdarwis.

Politeknik Negeri Sriwijaya juga memberikan pendampingan dan pelatihan kepariwisataan kepada masyarakat. Adapun bentuk pelatihan yang diberikan antara lain seperti pelatihan tentang hospitality serta edukasi penerapan sapta peson di destinasi wisata.

Pemangku kepentingan yang paling utama dalam kelompok pendukung ini adalah tokoh masyarakat. Dalam memberikan gagasan, dia tidak memiliki kepentingan secara personal sehingga tokoh masyarakat memiliki pengaruh yang tinggi sebagai penyumbang ide dan mencari investor untuk bekerjasama membangun pariwisata desa. Pengembangan ekowisata dilakukan untuk memberikan manfaat kesejahteraan kepada masyarakat desa dan sebagai media promosi daerah. Hal ini merujuk pada hasil wawancara kepada tokoh masyarakat yang menyebutkan:

"...dalam pengembangan ekowisata, kami tidak memiliki kepentingan apaun secara pribadi, semua dilakukan untuk masyarakat"

\section{Kuardan IV (Pengikut)}

Pemangku kepentingan yang berada pada kuadran IV disebut sebagai pemangku kepentingan pengikut. Pemangku kepentingan ini memiliki kepentingan dan pengaruh yang rendah. Sekali lagi, pernyataan Reed et al., (2009), bahwa pemangku kepentingan pengikut tidak memiliki pengaruh yang signifikan karena tidak terlibat secara keseluruhan dalam manajemen pengembangan ekowisata, relevan dengan gambaran empirik ini. Karang
Taruna sendiri merupakan satu-satunya pemangku kepentingan yang memiliki kepentingan dan pengaruh yang lemah, sehingga perannya terbatas hanya sebagai pengawas. Hal ini merujuk pada hasil wawancara bersama Ketua Karang Taruna yang menyatakan bahwa:

"...karang taruna tidak terlibat secara langsung dalam pengelolahan, kami memiliki tugas dari kepala desa untuk mengawasi dan mengevaluasi kegiatan pariwisata."

\section{SIMPULAN DAN SARAN}

Berdasarkan hasil analisis diatas, terdapat tiga belas pemangku kepentingan yang terlibat dalam pengembangan ekowisata di Desa Ekowisata Burai yang terdiri dari lima sektor yakni sektor pemerintah, sektor swasta, sektor akademisi, sektor lembaga swadaya masyarakat dan sektor masyarakat.

Terdapat tiga variasi peran yang berbeda yang dimiliki oleh para pemangku kepentingan yakni: regulator, fasilitator dan pelaksana. Klasifikasi peran yang dimiliki oleh para pemangku kepentingan juga ditentukan berdasarkan penempatan kuadran masing-masing peran yaitu; subjek, pendukung, pemain kunci dan pengikut.

Temuan dalam penelitian ini menunjukkan jika terdapat banyak pemangku kepentingan yang terlibat, kontribusi peran yang diberikan tentunya bertujuan untuk membantu pengembangan desa serta memberikan manfaat bagi masyarakat lokal. Bentuk kontribusi berupa pelatihan yang diberikan kepada masyarakat didominasi oleh sektor pemerintah, namun seringkali topik pelatihan pada program tersebut tidak memiliki relevansi terhadap kebutuhan masyarakat lokal. Selain itu narasumber pada program pelatihan juga dipandang tidak memiliki kompetensi teknis yang sangat dibutuhkan untuk penguatan kapasitas ketrampilan peserta pelatihan. Oleh sebab itu, perlu dilakukan kajian lebih lanjut tentang efek positif pelatihan yang diberikan oleh pemerintah kepada 
masyarakat untuk meningkatkan kompetensi pengelolaan ekowisata desa. Di samping itu perlu kajian sejenis untuk menemukan efektivitas kontribusi pemangku kepentingan yang relatif besar dalam pengembangan ekowisata: benarkan jumlah pemangku kepentingan yang banyak, dapat menentukan keberhasilan ekowisata berbasis masyarakat di tingkat perdesaan?

\section{DAFTAR PUSTAKA}

Anwar. (2007).

Manajemen Permberdayaan Perempuan (Perubahan Sosial Melalui Pembelajaran Vocational Skill Pada Keluarga Nelayan). Alfabeta.

Bryson, J. M. (2004). What to do when stakeholders matter: Stakeholder Identificatixon and analysis techniques. Public Management Review, 6(1), 21-53. https://doi.org/10.1080/1471903041 0001675722

Chachava, N. T., dan Khoshtaria, T. K. (2017). Prosepects of ecotourism development in recreation areas of South Georgia. Annals of Agrarian Science, 15(3), 312-317.

Choi, H. S. C., \& Sirakaya, E. (2006). Sustainability Indicators for Managing Community Tourism. Tourism Management, 27(6), 1274-1289.

https://doi.org/10.1016/j.tourman.20 05.05 .018

Creswell, J. W. (2013). Research Design Pendekatan Kualitatif, Kuantitatif, Dan Mixed. Pustaka Pelajar.

Damanik, J., dan Weber, H. F. (2006). Perencanaan Ekowisata: dari Teori ke Aplikasi. Yogyakarta: PUSPAR UGM dan Andi.

Damanik, J. (2016). Lack of Stakeholder Partnerships in DestinationManagement: Lessons Learned from LabuanBajo, Eastern Indonesia. Asian Journal of Tourism Research, 1(2), 173198.
Diamantis, D. (2018). Stakeholder ecotourism management: exchanges, coordination's and adaptation. Journal of Ecotourism, 17(3), 203-205.

Fennell, D. A. (2008). Ecotourism. New York: Routledge.

Gunawan, S. (2009). Pemberdayaan Masyarakat dan Jaringan Pengaman Sosial. PT Gramedia Pustaka Utama.

Hill, J., dan Gale, T. (2009). Ecotourism and environmental sustainability: principles and practice. Burlington, USA: Ashgate.

Kiper, T. (2013). Role of Ecotourism in Sustainable Development. DOI: $10.5772 / 55749$.

Maryono, E., Kuswanto, S., Getteng, M., Ahmad, S., \& Mulyasari. (2005). Pelibatan Publik Dalam Pengambilan Keputusan (Public Involvement in Decision Making). LP3ES, ed.

Mathis, R. L. (2000). Human Resource Management. South-Western College Pub.

Prastika, H. C. (2017). Peran Pemerintah Daerah dan Partisipasi Pelaku Usaha Mikro Kecil Menengah (UKMK) dalam Upaya Pengembangan Kerajinan Kulit di Kabupaten Magetan. In Universitas Airlangga, Fakultas IImu Sosial dan IImu Politik. Universitas Airlangga.

Reed, M. S., Graves, A., Dandy, N., Posthumus, H., Hubacek, K., Morris, J., Prell, C., Quinn, C. H., \& Stringer, L. C. (2009). Who's in and why? A typology of stakeholder analysis methods for natural resource management. Journal of Environmental Management, 90(5), 1933-

1949.https://doi.org/10.1016/j.jenv man.2009.01.001

Rohaniyah, S. (2005). Pola Pemberdayaan Pemuda Dengan Pelatihan Budidaya Ayam Arab di BPPLSP Regional III Jawa Tengah. Universitas Negeri Semarang.

Saidmamatov, O., Matyakubov, U., Rudenko, I., Filimonau, V., Day, J., 
dan Luthe, T. (2020). Employing Ecotourism Opportunities for Sustainability in the Aral Sea Region: Prospects and Challenges. Sustainability, 12(21), 9249; https://doi.org/10.3390/su12 219249

Sekhri, S. (2009). The Role Approach As a Theoretical Framework For the Analysis of Foreign Policy in Third World Countries. African Journal of Political Science and International Relations, 3(10), 423432.

http://www.academicjournals.org/aj psir

Sembiring, E., \& Basuni, S. (2010). Resolusi Konflik Pengelolaan Taman Nasional Teluk Cenderawasih di Kabupaten Teluk Wondama. 14(2), 84-91.

Sheng-Hshiung, T., Lin, Y.-C., \& Lin, J.$\mathrm{H}$. (2006). Evaluating Ecotourism Sustainability From the Integrated Perspective of Resource, Community and Tourism. Tourism Management Journal, 27(4),640653.

https://doi.org/10.1016/j.tourman.20 05.02 .006

Sugiyono. (2009). Metode Penelitian Pendidikan (Pendekatan Kuantitatif, Kualitatif dan R\&D). Penerbit CV. Alfabeta.

Sulistyani, A. T. (2004). Kemitraan dan Model-model Pemberdayaan. Penerbit Gava Media.

Sunaryo, B. (2013). Kebijakan Pembangunan Destinasi Pariwisata Konsep dan Aplikasinya di Indonesia. Gava Media.

Walter, P. G. (2016). Catalysts For Transformative Learning in Community-Based Ecotourism. Current Issues in Tourism, 19(13), 1356-1371.

https://doi.org/10.1080/13683500.2 013.850063

Werther,Jr., W. B. (1996). Human Resources and Personnel Management. McGraw-Hill.
Wiseza, F. C. (2017). Faktor-Faktor yang Mendukung Pengembangan Obyek Wisata Bukit Khayangan di Kota Sungai Penuh Provinsi Jambi. Nur El-Islam, 4(1), 89-106.

Zubayr, M., Darusman, D., Nugroho, B., \& Ridho Nurrochmat, D. (2014). Peranan Para Pihak Dalam Implementasi Kebijakan Penggunaan Kawasan Hutan Untuk Pertambangan. Jurnal Analisis Kebijakan Kehutanan, 11(3), 239-259. https://doi.org/10.20886/jakk.2014. 11.3.239-259. 